\title{
MENAKAR STRATEGI GOVINDA SPORT MENYIKAPI PERUBAHAN PERILAKU KONSUMEN DARI KONVENSIONAL KE ONLINE SHOPPING
}

\author{
I Wayan Govinda Gotama Putra ${ }^{1}$ \\ Gede Sri Darma² \\ Universitas Pendidikan Nasional, Bali, Indonesia \\ email: govindagotamap@gmail.com ${ }^{1}$ \\ sridarma@undiknas.ac.id ${ }^{2}$
}

\begin{abstract}
ABSTRAK
Tujuan penelitian ini adalah untuk mengetahui strategi yang tepat dalam mengatasi perubahan perilaku konsumen dari konvensional ke online shopping dan Govinda Sport Denpasar. Penelitian ini menggunakan metode kualitatif dengan pendekatan deskriptif. Teknik pengumpulan data menggunakan in depth interview menggunakan aplikasi Zoom. Informan ditentukan secara purposive sampling. Hasil penelitian menunjukkan online shopping lebih efisien waktu, terdapat banyak varian produk dan bisa berkomunikasi lebih baik. Namun, tidak dapat melihat kondisi fisik barang secara langsung dan risiko barang rusak saat pengiriman. Toko Govinda Sport telah menerapkan strategi Bauran Pemasaran pada toko konvensional dan Online. Namun keuntungan yang didapat dari online masih jauh lebih sedikit dengan keuntungan pada konvensional, karena tingkat penjualan yang masih rendah dan belum terdapat SDM yang memiliki keahlian dibidang digital marketing. Strategi yang dilakukan manajemen adalah menambah SDM dibidang digital marketing, melakukan promosi di Instagram dan kemudian mendorong kosumen untuk bertransaksi melalui toko online Govinda Sport yang di marketplace

Kata kunci : Perilaku konsumen, strategi pemasaran, online shopping, bauran pemasaran
\end{abstract}

\begin{abstract}
The purpose of this study is to determine the right strategy in dealing with changes in consumer behavior from conventional to online shopping, conducted at Govinda Sport Denpasar. This research uses qualitative methods with descriptive approach. Data collected through in-depth interviews and using Zoom. The informans were determined by purposive sampling. The results show that online shopping provides time efficiency, more product variants and better communication however, consumer cannot see physical condition of the goods directly and the risk of goods being damaged during delivery. Govinda Sport has implemented Marketing Mix strategy in conventional and online stores but the profit obtained from online business are still far less, this is due to the low level of sales and there is no staff who have expertise in digital marketing. The management should hire digital marketing expert, doing promotions on Instagram and encouraging consumers to purchase through online store in marketplace.
\end{abstract}

Keywords: consumer behavior, marketing strategies, online shopping, marketing mix 


\section{PENDAHULUAN}

Dunia terus berkembang dan berubah, dimana di era sekarang semuanya telah berbasis digital. Digitalisasi telah mencakup hingga ke kehidupan manusia seharihari contohnya adalah smarthphone dan internet Di era revolusi industri 4.0, manusia amat sulit untuk dipisahkan dengan kedua hal tersebut, dengan berkembangnya teknologi yang semakin pesat, smartphone tidak hanya sekedar menjadi alat komunikasi dua orang, dibarengi dengan teknologi internet, kedua teknologi canggih ini telah banyak merubah tatanan kehidupan dunia, salah satunya dalam bidang ekonomi. Melalui smartphone yang tersambung dengan internet, kini seseorang dapat melakukan transaksi jual beli produk ataupun jasa yang dia miliki. Menurut Maharani \& Darma (2018), "Para pelaku usaha ritel dewasa ini dituntut untuk bisa mengikuti perkembangan zaman yang bertujuan untuk meningkatkan kreatifitas serta berinovasi dalam bidang ketersediaan produk, mengetahui kebutuhan pelanggan, bentuk pelayanan yang diberikan dan juga mampu melihat perilaku dari konsumen."

Dunia bisnis saat ini dilaksanakan di dunia digital yang menghubungkan orang dan perusahaan. Internet, jaring publik luas dari jaringan komputer, menghubungkan segala jenis user di seluruh belahan dunia yang menghubungkan mereka dengan penyimpanan informasi yang sangat besar. Internet telah memberikan marketer cara baru untuk menciptakan nilai bagi pelanggan dan membangun hubungan kepada pelanggan. (Darmawan \& Ekawati, 2017; Putri \& Sudiksa, 2018). Internet telah dipersepsikan sebagai media yang tepat untuk sarana komunikasi dengan konsumen, serta upaya menarik perhatian (atention) dan ketertarikan (interest) konsumen pada produk (Sutedjo \& Oetomo, 2015)

Perkembangan penggunaan internet saat ini mendorong adanya suatu potensi besar terciptanya belanja online. Online shopping telah menjadi fenomena pada saat ini karena dinilai lebih praktis. (Devi \& Sulistyawati, 2018; N. L. P. A. Maharani \& Ekawati, 2019; Nusarika \& Purnami, 2015; Sujana \& Suprapti, 2016).

Tabel 1.

Peta E-commerce Indonesia Kuartal III

\begin{tabular}{ccccc}
\hline No. & Toko Online & Visitor per Bulan & $\begin{array}{c}\text { Peringkat } \\
\text { Appstore }\end{array}$ & $\begin{array}{c}\text { Peringkat } \\
\text { Playstore }\end{array}$ \\
\hline 1 & Shopee & 93.440 .330 & 1 & 1 \\
2 & Tokopedia & 86.103 .300 & 2 & 3 \\
3 & Bukalapak & 35.288 .100 & 4 & 4 \\
4 & Lazada & 22.021 .800 & 3 & 2 \\
5 & Blibli & 18.307 .500 & 6 & 6 \\
\hline
\end{tabular}

Sumber: www.iPrice.co.id (2020)

Keberadaan online marketing, tidak hanya memudahkan penjual untuk menjual barangnya kepada calon pembeli, namun keuntungan juga akan dirasakan oleh pembeli, melalui transaksi online pembeli barang atau jasa tidak perlu keluar rumah untuk menemukan gerai demi mengkonsumsi barang atau jasa yang ia inginkan. Kurir jasa pengantar barang, akan langsung mengantarkan produk atau 
jasa yang ia pesan. Pembayaran juga disediakan dengan berbagai cara mulai dari transfer bank, kredit ataupun melalui uang digital. Kemudah-kemudahan yang ditawarkan transaksi online, nampaknya telah membuat masyarakat "kecanduan". Masyarakat menjadi cenderung malas keluar rumah demi menemukan produk atau jasa yang ia cari. Telah terjadi fenomena social, dimana perilaku konsumen telah berubah dari yang tadinya mencari suatu barang, menjadi "barang yang mencari konsumen itu". Penjual akan semakin dimudahkan untuk menemukan calon pembeli, di dunia maya. Menurut ( Maharani \& Darma, 2018) Para pelaku usaha ritel dewasa ini dituntut untuk bisa mengikuti perkembangan zaman yang bertujuan untuk meningkatkan kreatifitas serta berinovasi dalam bidang ketersediaan produk, mengetahui kebutuhan pelanggan, bentuk pelayanan yang diberikan dan juga mampu melihat perilaku dari konsumen.

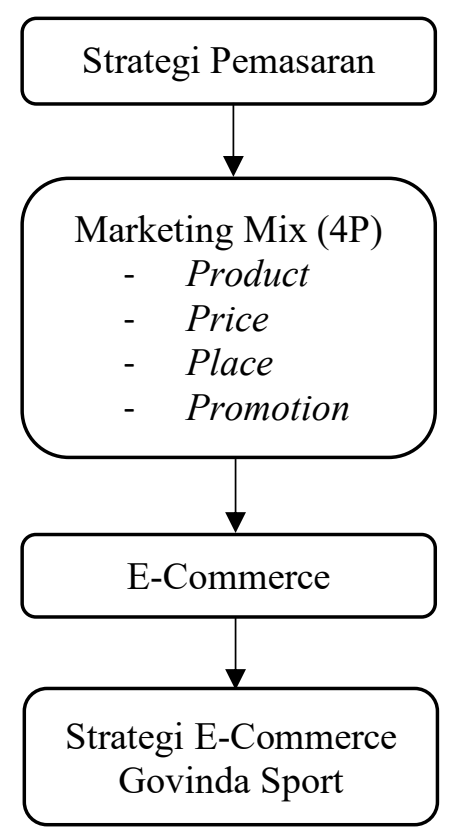

\section{Gambar 1. Kerangka Konseptual}

Sumber: Dikembangkan dari penelitian Mahardika (2019)

Pemasaran merupakan komponen yang selalu ada didalam sebuah bisnis. menurut (Adnyana \& Darma, 2015) pemasaran adalah suatu proses sosial dan manajerial yang didalam dan kelompok mendapatkan apa yang mereka butuhkan dan inginkan, dengan menciptakan, menawarkan dan mempertukarkan produk yang bernilai dengan pihak lain. Sedangkan menurut (Widani et al., 2019) Pemasaran adalah kegiatan atau proses mengkomunikasikan barang atau jasa yang bertujuan untuk menciptakan, mengembangkan dan mengekalkan pelanggan dalam suatu aktivitas ekonomi atau pertukaran barang dimana penjualan merupakan suatu bagian daripada pemasaran. Proses jual beli Online berbeda dengan proses jual beli tradisional dimana semua proses mulai dari mencari informasi mengenai barang atau jasa yang diperlukan, melakukan pemesanan hingga pembayaran dilakukan secara elektronik. 
Menurut Pupuani \& Sulistyawati (2013), "perusahaan dalam mencapai tujuan pemasarannya di dalam pasar sasaran menggunakan seperangkat alat pemasaran bernama bauran." Untuk meningkatkan kepuasan pelanggan agar pelanggan mau membeli kembali produk tersebut terus menerus, salah satustrategi pemasaran yang dapat dilakukan perusahaan untuk meningkatkan kepuasan konsumen dan niat pembelian ulang adalah bauran pemasaran (marketing mix). Variabel bauran pemasaran telah banyak digunakan dalam penelitian terdahulu oleh beberepa peneliti. Penelitian Pratiwi \& Mandala (2015) memaparkan bahwa "bauran pemasaran merupakan variabel paling dominan yang berpengaruh terhadap keputusan pembelian Kebaya border pada Jegeg Ayu Boutique di Kuta."

Tanzil \& Kusuma (2015), Hanaysha (2018), Foster \& Johansyah (2019) menunjukan "produk (product) adalah barang atau jasa yang akan diterima seorang pembeli ketika mereka mengeluarkan sejumlah uang dimana hasil produk berpengaruh signifikan pada keputusan pembelian ulang, ini berarti meningkatnya kualitas produk yang ditawarkan"

Adinata \& Yasa (2018), Uslu \& Huseynli (2018), Suhaily \& Soelasih (2017), Yasri et al. (2020) menunjukkan, "price adalah jumlah uang yang dibutuhkan untuk mendapatkan suatu barang beserta pelayanannya. Setelah produk yang diproduksi siap untuk dipasarkan, maka perusahaan akan menentukan harga dari produk tersebut. Hasil penelitian juga menunjukkan hasil variabel persepsi harga berpengaruh positif dan signifikan terhadap niat beli kembali”

Dikutip dari Tejantara \& Sukawati (2018), Solihin et al. (2019), Edward \& Wibowo (2019) "Place adalah kegiatan atau fungsi untuk memindahkan produk atau jasa disertai dengan hak pemiliknya dari produsen ke konsumen akhir atau pemakai." Tanzil \& Kusuma (2015) menunjukan, "tempat berpengaruh signifikan pada keputusan pembelian ulang,ini berarti meningkatnya kualitas produk yang ditawarkan, maka akan meningkat pula keputusan pembelian ulang"

Berdasarkan Tanzil \& Kusuma (2015), Martha et al. (2019), Sianturi et al. (2019), "Promosi (promotion) adalah strategi dalam mengkomunikasikan informasi produk atau jasa dari penjual kepada pembeli. Promosi berpengaruh signifikan pada keputusan pembelian ulang, ini berarti meningkatnya kualitas produk yang ditawarkan, maka akan meningkat pula keputusan pembelian ulang"

Pemasaran berbasis digital atau E-commerce memanfaatkan internet sebagai media pendistribusian informasi. E- commerce adalah sistem yang dibangun untuk media promosi memperkenalkan barang atau jasa kepada calon customer melalui sistem elektronik (Handika et al., 2018). Berdasarkan Endyana \& Ardani (2019), "Kemajuan dari pengguna internet di Indonesia yang terus berkembang, membuat munculnya idustri perdagangan yang disebut dengan marketplace atau sering dikatakan dengan mall online. salah satu marketplace yang menarik di masa perkembangan e-commerce di Indonesia salah satunya Tokopedia yang didirikan pada tahun 2009, Tokopedia sendiri berhasil menjadi pionir perkembangan ecommerce di Indonesia, dari kemunculan Tokopedia inilah mendorong banyak pesaing di industri yang sama bermunculan seperti Bukalapak di tahun 2010, Lazada di tahun 2012, OLX di tahun 2014, Shopee di tahun 2015."

Sidharta \& Boy Suzanto (2015) mengemukakan, "Peluang bisnis yang besar membuat pelaku bisnis bergerak untuk selalu dapat mengikuti perkembangan 
teknologi yang ada, seperti trend saat ini menggunakan media sosial yang bukan hanya dipergunakan untuk berinteraksi jarak jauh tetapi sebagai media jual-beli produk atau jasa. Banyak bisnis yang masih tergolong kecil berhasil mendapatkan keuntungan yang besar berkat penggunaan media sosial." Konsumen dapat mempengaruhi konsumen lain melalui review mereka tentang produk bersangkutan di media sosial, dimana hal ini memberikan dampak langsung terhadap keinginan membeli konsumen akan suatu produk (Tuten \& Perotti, 2019). Salah satu aplikasi yang bisa digunakan adalah Instagram. Berdasarkan Martinayanti \& Setiawan (2016), "Instagram banyak memberikan manfaat bagi pemasar dan konsumen dalam pemasaran online. Pemasar dapat mengunggah gambar produknya pada Instagram yang secara otomatis gambar yang sama akan terunggah juga pada media social lainnya sehingga pengaplikasiannya menjadi sangat praktis. Manfaat lainnya bagi pemasar adalah dapat lebih hemat biaya beriklan, mudah mengetahui respon dari konsumen yang berminat membeli produk tersebut, dan merupakan media sosial yang banyak digunakan saat ini oleh semua kalangan sehingga sangat dekat dengan konsumen."

Darmawan \& Ekawati (2017). Mahardhika \& Sunariani (2019) menemukan bahwa "penggunaan media sosial Instagram untuk mempopulerkan dan mempromosikan produk catering di dunia maya, terbilang efektif dan juga menghasilkan tambahan pendapatan. Penggunaan strategi pemasaran menggunakan Instagram lebih bermanfaat daripada menggunakan cara konvensional lainnya." Putra \& Prianthara (2019) memaparkan "pemasaran dengan E-commerce dan pemutahiran web yang terintegrasi dengan mobile system dengan perubahan ini diharapkan dapat mengurangi pemasaran yang bersifat konvensional yang dinilai memerlukan biaya tinggi." Penelitian yang dilakukan oleh Dewi \& Darma (2019) memaparkan, "Grab telah sukses menerapkan prinsip marketing 4.0 melalui human centric brand image dengan mengkombinasikan teknologi, bakat, dan pemasaran 4.0 menggunakan online dan offline channels."

Namun dikutip dari penelitian Pee (2016) "pemasaran dan penjualan secara online selain berdampak dapat memperluas pemasaran produk namun juga pemasaran dan penjualan secara online tak bisa lepas dari ulasan online negatif dimana ulasan negatif ini memiliki jangkauan yang lebih luas, berdiam lebih lama, dan mengancam reputasi produk dan penjual produk". Selain itu dikutip dari penelitian Maia et al. (2019), "penjualan secara online dengan pencarian harga yang lebih mudah membuat skema perang harga tak bisa dihindari karena konsumen cenderung mencari harga yang paling kompetitif'. Selain itu berdasarkan Mulya Firdausy \& Idawati (2017) dan Arthur et al. (2019), promosi tidak berpengaruh signifikan terhadap keputusan pembelian pelanggan

\section{METODE PENELITIAN}

Penelitian ini menggunakan metode kualitatif dengan pendekatan deskriptif. Penelitian ini dilakukan untuk mengetahui strategi yang tepat bagi Govinda Sport, dalam menyikapi perubahan perilaku kosumen ke online shopping. Teknik pengumpulan data yang digunakan dalam penelitian ini adalah wawancara dengan in depth interview secara face to face dan menggunakan aplikasi Zoom, karena sedang dalam pandemic Covid-19. Informan ditentukan secara purposive sampling 
dimana informan adalah manajemen dari Govinda Sport dan konsumen alat-alat olahraga yang berdomisili di Kota Denpasar. Lokasi penelitian ini dilakukan di Kota Denpasar dan UD. Govinda Sport.

Strategi pemasaran merupakan penyusunan rencana, tahapan dan cara-cara untuk mencapai kegiatan atau proses mengkomunikasikan barang atau jasa kepada pelanggan. (Widani et al., 2019). Menurut Vinerean (2017), "Dengan kemajuan teknologi, pemasaran telah memasukkan interaktivitas yang disediakan oleh teknologi untuk menciptakan saluran komunikasi dua arah dengan pelanggan saat ini dan pelanggan potensial. Menggunakan teknologi berbasis internet, pemasaran mendorong partisipasi aktif konsumen". Dikutip dari Li et al. (2021) "bagi sebagian besar perusahaan, tantangan yang sedang berlangsung bukanlah memulai kampanye media sosial, tetapi menggabungkan media sosial dengan strategi pemasaran mereka untuk melibatkan pelanggan guna membangun hubungan yang berharga dan jangka panjang dengan mereka."

Dikutip dari Tejantara \& Sukawati (2018), "Bauran pemasaran terdiri dari 4P, yaitu: 1) Produk (product) adalah barang atau jasa yang akan diterima seorang pembeli ketika mereka mengeluarkan sejumlah uang. Barang atau jasa tersebut yang kita jual biasanya bukan hanya sekedar menjual produk, tetapi juga kualitas pelayananya. Inilah yang bisa menjadi daya tariktersendiri bagi kita yang menawarkan nilai tambah. 2) Price (harga) jumlah uang yang dibutuhkan untuk mendapatkan suatu barang beserta pelayanannya. Setelah produk yang diproduksi siap untuk dipasarkan, maka perusahaan akan menentukan harga dari produk tersebut. 3) Place adalah kegiatan atau fungsi untuk memindahkan produk atau jasa disertai dengan hak pemiliknya dari produsen ke konsumen akhir atau pemakai. 4) Promosi (promotion) adalah strategi dalam mengkomunikasikan informasi produk atau jasa dari penjual kepada pembeli.

Berdasarkan Widana \& Darma (2018) "E-commerce merupakan teknologi dinamis, aplikasi dan proses bisnis yang menghubungkan perusahaan, konsumen dan komunitas tertentu serta juga merupakan suatu cara berbelanja atau berdagang secara online atau direct selling yang menggunakan fasilitas internet, dimana terdapat website yang dapat menyediakan pelayanan get $\&$ deliver yang juga akan merubah semua kegiatan marketing dan sekaligus memangkas biaya-biaya operasional untuk kegiatan perdagangan yang menggunakan sarana computer atau gadget."

Teknik pengumpulan data yang digunakan dalam penelitian ini adalah sebagai berikut: 1) Wawancara, Wawancara adalah teknik pengumpulan data yang dilakukan dengan cara bertemu langsung dengan subyek penelitian yang berkaitan langsung dengan obyek yang diteliti. Teknik wawancara yang digunakan dalam penelitian ini adalah wawancara mendalam (in depth interview) dengan jenis wawancara komunikasi semi terstruktur, dimana wawancara dilakukan secara face to face dan menggunakan aplikasi Zoom, karena sedang dalam pandemic Covid-19 dengan transkrip wawancara sebagai panduannya. (Sugiyono, 2018) didalam melakukan wawancara, peneliti mendengarkan secara teliti dan mencatat apa yang dikemukankan oleh informan, yaitu manajemen Govinda Sport dan konsumen alatalat olahraga. 2) Dokumentasi, hasil penelitian akan lebih kredibel apabila didukung dengan bukti dokumentasi, maka dalam penelitian ini akan dilakukan 
dokumentasi berupa rekaman suara saat wawancara, screenshot penjualan pada Shopee dan Instagram. Govinda Sport. Dokumentasi dalam penelitian ini berupa foto dan hasil rekaman wawancara.

Metode keabsahan data yang digunakan dalam penelitian ini adalah metode triangulasi, dimana metode triangulasi yang digunakan adalah : 1) Triangulasi Sumber, Triangulasi sumber dilakukan dengan memeriksa data yang telah diperoleh melalui beberapa sumber. 2) Triangulasi Teknik, dilakukan dengan cara memeriksa data yang telah diperoleh melalui sumber yang sama dengan teknik yang berbeda.

\section{HASIL DAN PEMBAHASAN}

Penelitian ini dilakukan di UD. Govinda Sport yang beralamatkan di Jalan Hasannudin no. 2 Denpasar. Informan penelitian yaitu berjumlah 6 Orang, terdiri dari 1 orang owner, 1 orang manager, 1 orang staf, dan 3 konsumen Govinda Sport yang berdomisili di Kota Denpasar. Ketiga konsumen olahraga merupakan olahragawan yang sudah lebih dari 10 tahun berkecimpung di dunia olahraga. Salah satu dari informan konsumen olahraga, merupakan pelatih olahraga yang memiliki wawasan yang cukup baik di dunia olahraga, dan bisa menjadi influencer dari konsumen-konsumen olahraga. Wawancara telah sangat banyak menemukan informasi yang diterima terkait dengan strategi Marketing Mix pada UD. Govinda Sport untuk beradaptasi di era Revolusi 4.0. Selain informasi dari manajemen UD. Govinda Sport, informasi juga didapatkan dari konsumen mengenai perubahan perilaku konsumen ke dunia digital. Secara umum menemukan bahwa perusahaan telah menyiapkan strategi untuk beradaptasi dengan perubahan perilaku konsumen ke online shopping. Data yang ditemukan pada konsumen menunjukan terjadi shifting perilaku kosumen dari konvensional ke online shopping. Temuan yang didapatkan dari sisi konsumen dan juga dari sisi penjual, telah menunjukan fenomena baru dari dunia bisnis olahraga, yaitu ekonomi digitial.

Govinda Sport adalah Usaha Dagang atau yang biasa disingkat "UD" yang menjual alat-alat olahraga dan pakaian olahraga. Perusahaan Govinda Sport berdiri pada tahun 2005 yang artinya sudah 15 tahun melayani dan menjual alat-alat olahraga untuk masyarakat Bali. Perusahaan Govinda Sport beralamatkan di Jalan Hasannudin nomor 2, Dauh Puri Kangin, Kecamatan Denpasar Barat, Kota Denpasar, Bali. Govinda Sport buka dari Hari Senin sampai Hari Minggu. Jam operasional 08.30 - 20.30 untuk Hari Senin sampai dengan Sabtu, sedangkan untuk Hari Minggu jam $08.30-17.00$.

Jenis perlengkapan olahraga yang dijual meliputi: Bulutangkis, Tenis, Tenis Meja, Bola Voli, Bola Basket, Sepak Bola, Atletik, Billiard dan alat musik serta perlengkapan penunjang olahraga lainnya. Selain perlengkapan olahraga, Govinda Sport juga menjual jasa berupa instalasi senar raket bulutangkis, jasa pemasangan senar raket tenis serta jasa pemasangan karet bet tenis meja dengan didukung stringer professional yang sudah lebih dari 15 tahun menggeluti profesi ini. Produk lain yang dijual adalah piala, plakat dan medali. Govinda Sport akan terus berinovasi, khususnya dibidang teknologi dan informasi, sehingga dapat berkembang dan tumbuh menjadi perusahaan yang lebih besar lagi. 
Transaksi secara online sudah menjadi hal yang lumrah di era modern saat ini. Berdasarkan data yang diperoleh ketiga informan sudah pernah Transaksi Online. Beberapa informan bahkan akan lebih cenderung kedepannya untuk melakukan belanja alat-alat olahraga melalui toko online seperti informan $\mathrm{KW}$ dan KSP. Seperti yang disampaikan dalam kutipan wawancara beikut: "sepertinya belum akan meninggalkan sepenuhnya, maksudnya blanded antara konvensional dengan online. Rasanya saya bakal lebih sering online, mungkin porsinya 70\% untuk online dan 30\% untuk konvensional” (KW, Komunikasi Personal, 2021)

"Iya Mungkin bisa kedepannya, karena kan kedepannya pasti alangkah lebih baiknya kalau bisa dilakukan secara online karena teknologi sekarang kan sudah semakin maju” (KS, Komunikasi Personal, 2021)

Sedangkan informan RRG masih melakukan mix transaksi antara online dan konvensional. Media berbelanja online sudah banyak tersedia, menjadikan konsumen bebas memilih dimana media yang diinginkan untuk melakukan transaksi online. Seperti yang di sampaikan oleh informan KW pada kutipan wawancara berikut ini: "Platform e-commerce, seperti Tokopedia, Shopee, kadang juga kalau sellernya itu punya Whatsapp, Line, Instagram, biasanya lebih enak dari sana sih daripada website e-commerce." (KW, Komunikasi Personal, 2021). Selain itu informan KSP dan RRG juga sudah pernah melakukan transaksi online melalui Marketplace. Peneliti melihat suatu yang menarik dari Sudah pernah belanja online, Media Berbelanja Online, dan Berpindah ke Online yang dapat dikelompokan menjadi Pengalaman Belanja Online.

Pengalaman Belanja Online dilakukan karena adanya Kelebihan Belanja Online. Informan di Kota Denpasar mengaku melakukan belanja online karena mengalami sejumlah kelebihan ketika berbelanja melalui internet. Ketida. Informan konsumen (KW, KSP, dan RRG) misalnya, menjawab bahwa belanja online membuat mereka mendapat efisiensi waktu dan tenaga. Seperti yang di kutip dari wawancara berikut ini: "Kalau misalkan online saya gaperlu ribet ke toko fisiknya, dan lebih ringkas aja saya make online dibandingkan datang ke toko” ( $K W$, Komunikasi Personal, 2021)

"Keuntungan paling utama itu, kalo online itu jauh lebih praktis dan efisien dibandingkan datang langsung ke tokonya" (RRG, Komunikasi Personal 2021)

"Manfaatnya sangat banyak, efisiensi waktu, kalau dalam segi hemat waktu, mungkin saya akan sering transaksi online” (KSP, Komunikasi Personal, 2021)

Selain itu, beberapa keuntungan yang dirasakan informan yaitu kemudahan berkomunikasi dan kejelasan harga, Informan $\mathrm{KW}$ merasa harga pada toko online sudah jelas, karena harga sudah langsung tertera pada produk di toko online. Informan KW dan KSP merasa belanja di toko online barang lebih mudah dijangkau dijangkau, seperti yang dikutip dalam wawancara berikut ini:

"gaperlu ribet nyari barangnya juga karena semua ada disana, didalam katalog online biasanya" (KW, Komunikasi Personal, 2021)

"terus kita juga lebih melihat secara langsung barang-barang yang dibeli dari media online" (KW, Komunikasi Personal, 2021) 
Kelebihan belanja online selanjutnya adalah model produk, dimana informan RRG merasa model produk di toko online lebih lengkap, seperti yang dikutip dari wawancara berikut ini:

"Kalau misalnya transaksi sepatu nih, plusnya itu misalnya di toko konvensional mungkin tidak ada model sepatu yang saya cari, , tapi minusnya kalau toko online itu sepatunya bisa kebesaran atau kekecilan, jadi bisa kurang pas sepatunya kalau belanja online." (RRG, Komunikasi Personal, 2021)

Sedangkan menurut informan KW, kelebihan belanja online lainnya adalah rasa kemandirian terhadap diri sendiri, seperti yang dikutip dari wawancara berikut ini:

"Terus harus cari barang sendiri atau minta tolong orang kalau ke toko, ada sedikit rasa kemandirian mungkin berbelanja lewat online, control terhadap diri sendiri juga lebih kuat kalo online." (KW, Komunikasi Personal, 2021)

Transaksi online dilakukan dengan adanya tahapan-tahapan yang dilakukan oleh informan. Setiap informan memiliki caranya tersendiri dalam melakukan transaksi online. Ada informan yang langsung mencari nama produk yang dicari dan ada informan yang langsung mencari toko online yang sudah terpercaya. Seperti yang dilansir dari informan $\mathrm{KW}$, ia akan mencari nama produk yang dibutuhkannya terlebih dahulu setelah itu jika ada yang sesuai maka akan dilanjutkan untuk mengunjungi tokonya. Berbeda dengan yang dilakukan informan KSP dan RRG yang akan langsung mencari nama toko yang sudah dipercaya saat akan melakukan belanja online. Selanjutnya informan KSP akan melihat produk yang dijual toko online dan foto-foto produknya, seperti yang dikutip dari wawancara berikut ini: "Mungkin saya akan searching dulu tokonya, kemudian saya lihat produk-produknya, seperti yang saya bilang tadi itu, mungkin kan banyak keluar toko di beranda, tapi saya liat dari produknya, kalau dari foto produknya meyakinkan mungkin saya langsung kesana, tapi kalau dari fotonya kurang meyakinkan, saya jadi kurang percaya." (KSP, Komunikasi Personal, 2021)

Proses transaksi online terjadi karena adanya dorongan bagi konsumen untuk melakukan transaksi online. Dorongan yang timbul didasari oleh berbagai faktor, informan KW, KSP, dan RRG merasa kredibilitas suatu toko online menjadi faktor pendiring yang kuat untuk melakukan belanja online. Informan KW merasa lebih percaya dengan toko online yang sudah ada review dari konsumen lain. Senada dengan informan KW, informan KSP dan RRG juga akan semakin terdorong untuk melakukan transaksi online jika rating dan testimoni dari konsumen sebelumnya itu baik. Dorongan untuk bebrelanja online semakin kuat jika faktor ketersediaan barang, harga, jangkauan kerja dan pricelist tersedia pada toko online, seperti yang disampaikan oleh informan KW dalam kutipan wawancara berikut ini:

"menyediakan barang yang saya butuhkan, kalau dia punya jangkauan kerjanya sesuai dengan yang saya cari, harga dan ketersediaan barang, ada atau tidaknya pricelist di tokonya tersebut, kadang di online shop cuma display barang 
saja jadi tidak ada info buat konsumen, jadi kayak bingung sendiri, jadi atau tidak belanja" (KW, Komunikasi Personal, 2021)

Kelebihan melakukan belanja online tidak serta merta selalu menimbulkan rasa aman kepada konsumen saat melakukan transaksi. Terdapat beberapa kekurangan yang dirasakan oleh konsumen. Seperti yang dirasakan oleh informan $\mathrm{KW}$, KSP, dan RRG yang takut barang yang ditransaksikan secara online tidak sesuai saat dikirim ataupun diterima. informan KSP takut barangnya rusak saat di ekspedisi, seperti yang dikutip dalam wawacara berikut ini:

"karena saya belum bisa 100\% memberikan barang saya, misalnya saya mau memasang senar raket, saya belum bisa memberikan kepada grab atau gojek, karena saya takut barangnya rusak." (KSP, Komunikasi Personal, 2021)

Hal serupa juga dengan konteks yang sedikit berbeda juga disampaikan oleh informan KW, dimana ia takut salah dalam melakukan penilaian untuk barang premium yang harganya mahal saat transaksi melalui online, seperti yang dikutip dalam wawancara berikut ini:

"misalkan kalau kita belanja banyak atau belanja dengan jumlah besar ada risiko kalau kita hanya menilai secara online, tidak ketemu dengan barangnya dan gatau siapa sellernya, itusih yang saya pertimbangkan. Kalau misalkan dengan nominal kecil dan hal-hal biasa, lebih berani sih belanja online." $(K W$, Komunikasi Personal, 2021)

Keterbatasan dari tansaksi secara online, membuat belanja secara konvensional belum bisa ditinggalkan secara penuh oleh konsumen. Bahkan informan di Kota Denpasar mengaku masih melakukan belanja secara konvensional. Ketiga Informan konsumen (KW, KSP, dan RRG) misalnya, menjawab sekarang ini masih melakukan transaksi secara konvensional karena terdapat beberapa faktor yang membuat informan lebih nyaman dalam bertransaksi secara konvensional untuk beberapa produk tertentu. Informan RRG menjawab masih melakukan transaksi secara konvensional karena ingin melihat detail dan kondisi barang secara langsung, sedangkan informan KSP masih melakukan transaksi konvensional untuk penyenaran raket karena, takut barangnya rusak saat pengiriman ke toko. Disamping itu terdapat rasa aman untuk melihat kondisi barang secara langsung, khususnya untuk barang-barang premium. Seperti informan KW yang akan tetap melakukan transaksi online untuk produk tertentu, agar bisa melihat fisik produknya secara langsung. Seperti yang dikutip dari wawacara berikut ini:

"iya masih, untuk barang-barang yang mahal, atau lebih mahal dari biasanya, saya langsung datang ke toko, agar bisa melihat barangnya secara fisik. (KW, Komunikasi Personal, 2021)

Terjadinya fenomena perubahan perilaku konsumen yang sekarang sudah terbiasa berbelanja melalui media online, perusahaan harus dapat beradaptasi dengan dunia digital. Strategi perusahaan yang tepat dan dengan memanfaatkan teknologi yang ada merupakan salah satu cara agar perusahaan bisa beradaptasi di 
bisnis digital. Seperti yang sudah dijelaskan pada bagian sebelumnya, peneliti melakukan penilitian di perusahaan perlatan olahraga Govinda Sport.

Informan WW selaku owner Govinda Sport mengatakan bahwa perusahaannya sudah berdiri sejak tahun 2005, yang artinya sudah 15 tahun lebih. Perusahaan memiliki seorang Manajer berinisial MW yang juga akan menjadi informan pendukung. Informan MW mengatakan, bahwa dia sudah bekerja di Govinda Sport selama 14 tahun. Seorang staf senior berinisial WS juga menjadi informan pendukung selanjutnya, informan WS mengatakan bahwa dia sudah bekerja di Govinda Sport selama lebih dari 15 tahun.

Kemajuan teknologi telah membuat banyak perubahan di dunia bisnis. Tidak terkecuali di dunia bisnis alat-alat olahraga. Ketiga informan (WW, MW, dan WS) merasa bahwa konsumen alat-alat olahraga sekarang sudah semakin teredukasi tentang informasi dan spesifikasi produk. Seperti yang dikutip dalam wawancara berikut ini: "karena sekarang dengan berkembangnya teknologi ini, konsumen itu lebih teredukasi, jadinya, jadi dia itu sudah tau apa yang mau dicari, dengan varian spesifikasinya itu, jadi karena dia sudah searching dulu di internet, jadi dia juga bisa membandingkan harga-harga dengan di toko-toko yang lain" (WW, Komunikasi Personal, 2021)

"jadi konsumen juga gampang cari informasi tentang spesifikasi produk. Adanya marketplace juga berpengaruh dengan perubahan perilaku konsumen yang berbelanja lewat online, karena dia jadi bisa belanja dari rumahnya saja melalui smartphone, toko online juga sudah sangat banyak ada di marketplace." (MW, Komunikasi Personal, 2021)

"konsumen jadi lebih pintar dan sudah teredukasi tentang produk, konsumen sering membandingkan harga dengan toko online." (WS, Komunikasi Personal, 2021)

Shifting perilaku konsumen ke dunia bisnis online telah disadari oleh manajemen perusahaan. Ketiga informan sependapat bahwa shifting perilaku konsumen terjadi karena adanya kemajuan teknologi. Seperti yang dikutip dari wawancara berikut ini: "dengan kemajuan teknologi itu, jadi informasi teknologi yang semakin maju, konsumen bisa searching informasi itu di google misalnya, di internet sebelum melakukan pembelian" (WW, Komunikasi Personal, 2021)

"Penyebab utamanya kemajuan teknologi, adanya e-commerce, marketplace, jadi sekarang informasi produk itu sudah tersedia di internet, jadi" (MW, Komunikasi Personal, 2021)

"Penyebabnya mungkin kemajuan zaman dan teknologi, selanjutnya manfaat dari toko online tersebut, sehingga menguntungkan konsumen." (WS, Komunikasi Personal, 2021)

Shifting perilaku konsumen ke dunia digital telah membuat adanya tantangan baru bagi Govinda Sport. Salah satunya ada pengaruh E-commerce kepada jalannya perusahaan. Menurut inofrman WS , E-commerce cukup berpengaruh terhadap jalannya bisnis Govinda Sport, menjadi banyak orderan melalui Gojek dan Grab. Seperti yang dikutip dalam wawancara berikut ini: "Cukup berpengaruh ya untuk 
jalannya bisnis disini, kita jadi banyak orderan yang lewat gojek dan order lewat whatsapp ya." (WS, Komunikasi Personal, 2021)

Secara tidak langsung, keberadaan E-commerce telah membuat shifting budaya perusahaan di Govinda Sport, yang dulunya hanya bisa menerima transaksi konvensional, sekarang "dipaksa" untuk beradaptasi dengan kemajuan teknologi, seperti yang dikuti dari wawancara berikut ini: "E-commerce mulai merubah budaya ditoko kami, yang dulunya hanya bisa melayani konsumen secara konvensional tapi sekarang kami mau tidak mau harus bisa melayani konsumen melalui media online." (MW, Komunikasi Personal, 2021)

Sedangkan menurut informan WW, E-commerce memiliki pengaruh positif dan negatif terhadap perusahaannya. Pengaruh positif e-commerce bagi bisnisnya adalah, manajemen menjadi lebih mudah menyalurkan barangm menambah konsumen baru dan promosi yang lebih murah. Seperti yang dikutip dalam wawancara berikut ini: "lebih mudah kepada konsumen, jadi menambah konsumen baru, dari luar pulau juga bisa, karena kan dia bisa langsung liat ya di platform online. Jadi dengan itu, bisa juga melakukan promosi dengan biaya yang lebih murah dan juga meningkatkan penjualan jasa dan produk kami." (WW, Komunikasi Personal, 2021)

Senada dengan informan WW, informan MW juga menjawabh bahwa $E$ commerce memiliki dampak positif bagi perusahaan, salah satunya ada memperluas pangsa pasar dan promosi melalui Instagram. Seperti yang dikutip dari wawancara berikut ini: "kami jadi bisa memperluas pangsa pasar kami. Ternyata banyak konsumen yang belum mengetahui keberadaan toko kami, jadi dengan bantuan Instagram kami menjadi lebih mudah mempromosikan dan mengenalkan toko kami kepada masyarakat. Pertukaran informasi dari kami ke konsumen juga menjadi lebih mudah, bisa melauli aplikasi whatsapp. Adanya aplikasi ini mempermudah konsumen untuk memesan barang di toko kami, sehingga banyak transaksi yang kami lakukan melalui bantuan pengiriman Gojek atau Grab. Pelanggan biasanya menghubungi kami untuk menanyakan stock barang yang akan dibeli, dan selanjutnya memesan grab atau gojek untuk membeli barang dari toko kami"'(MW. Komunikasi Personal, 2021)

Informan (WW, MW dan WS) menjawab bahwa Govinda Sport sudah memiliki toko online, akan tetapi belum efektif berjalan dikarenakan belum memiliki SDM dibidang digital marketing. Menurut informan MW, untuk menjawab tantangan ini adalah merekrut tenaga ahli dibidang digital marketing. Seperti yang dikutip dari wawancara berikut ini: "kami membutuhkan tenaga yang ahli dalam bidang digital marketing, disini kami akan merekrut orang kompeten di bidang ini. (MW, Komunikasi Personal 2021)

Sedangkan menurut informan WW, untuk menjawab tantangan bisnis online, manajemen harus bisa mendorong transaksi online pada marketplace. Seperti yang dikutip dalam wawancara berikut ini: "kita akan membuat marketplace di shopee dan tokopedia sebagai media transaksi online, walaupun selama ini sudah, jadi lebih digencarkan lagi, karena marketplace ini tempat yang lebih aman untuk 
bertransaksi baik bagi konsumen maupun sebagai penjual dari pihak kami." (WW, Komunikasi Personal, 2021)

Persaingan bisnis yang semakin ketat dan tantangan bisnis digital harus disekapi dengan strategi yang tepat. Strategi harus dirumuskan dengan matang, baik strategi toko konvensional dan toko online. Salah satu strategi pemasaran yang bisa diterapkan adalah Marketing Mix 4P yang terdiri Product, Price, Place dan Promotion. Penerapan marketing mix pada Govinda Sport nampaknya sudah diterapkan sejak awal perusahaan berdiri, seperti yang disampaikan ketiga informan (WW, MW, WS), strategi pemasaran marketing mix sudah diterapkan dengan baik di perusahaan Govinda Sport. Marketing mix yang diterapkan pertama adalah strategi produk, dimana ketiga informan (WW, MW, dan WS) menjawab manajemen Govinda Sport hanya menjual produk original dan berkualitas tinggi. Seperti yang dikutip dari wawancara berikut ini: "produk, jadi kami menjual produk yang berkualitas tinggi, yang tentunya original, tapi disamping itu jadi kami juga menyediakan produk-produk mungkin yang lebih murah, dengan bervariasi harga untuk dapat dijangkau juga oleh masyarakat" (WW, Komunikasi Personal, 2021)

"Product, kami menjual produk berkualitas dan tentunya raket dan sepatu original” (MW, Komunikasi Personal, 2021)

"Kalo untuk Product yang dijual ditoko sangat berkualitas, kita juga engga jual barang palsu, dijamin original semua” (WS, Komunikasi Personal, 2021)

Menurut informan WW dengan menjalankan strategi produk yang hanya menjual produk orginial dan berkualitas akan meningkatkan kepercayaan konsumen terhadap perusahaan. Seperti yang dikutip dari wawancara berikut ini: "jadi dengan mempertahankan, menjual yang berkualitas dan original juga akan memberikan kepercayaan kepada konsumen, jadi dengan itu dia sudah tau "oh jadi sudah pasti original, jadi tidak ada yang palsu”, membangun image yang positif." (WW, Komunikasi Personal, 2021)

Senada dengan informan WW, menurut informan MW, dengan menjalankan strategi produk yang hanya menjual produk original dan berkualitas, akan membuat rasa aman dipihak konsumen. Seperti yang dikutip dari wawancara berikut ini: "sehingga tidak merugikan konsumen dan membuat rasa aman dipihak konsumen, karena kami menjual barang original." (MW, Komunikasi Personal, 2021)

Setelah menjalankan strategi product, manajemen juga memasang strategi harga yang kompetitif. untuk bisa bersaing dengan toko lainnya, perusahaan harus memasang harga yang kompetitif, ditambah lagi dengan kemunculan bisnis digital, dimana banyak sekali pesaing-pesaing baru yang memasang harga murah. Ketiga informan (WW, MW, dan WS) menjawab, bahwa manejemen Govinda Sport selalu memberikan harga yang kompetitif dan terbaik, untuk menyikapi persaingan di bisnis konvensional maupun bisnis online. seperti yang dikutip dalam wawancara berikut ini: "kami selalu memberikan harga yang terbaik, jadi kompetitif di pasaran, karena juga harus bisa bersaing, jadi kan karena konsumen sekarang 
sudah pintar-pintar juga, pasti memilih dengan harga yang terbaik" (WW, Komunikasi Personal, 2021)

"Harga kami juga bersaing dengan toko-toko lain nya, bahkan kami bisa memberikan harga yang lebih murah daripada toko lainnya, karena seringkali ditoko kami ini, negosiasi harga masih bisa terjadi, artinya masih bisa ditawarlah. Strategi kami adalah memberikan harga yang semurah-murahnya untuk konsumen" (MW, Komunikasi Personal, 2021)

"kalo untuk price, untuk harga atasan kami selalu memantau perkembangan harga pasar, dan ibu, bos saya selalu memberikan harga termurah dari pesaing lainnya." (WS, Komunikasi Personal, 2021)

Strategi berikutnya yang menunjang keberhasilan pemasaran perusahaan adalah strategi place. Strategi place merupakan, tempat perusahaan akan mendistribusikan produk dan jasa yang dimilikinya. Informan WW mengatakan sebelum memilih tempat usaha yang sekarang, telah dilakukan survey terlebih dahulu ke beberapa tempat. Informan WW dan MW menjawab, lokasi Govinda Sport saat ini merupakan lokasi yang strategis untuk menjalankan bisnis alat-alat olahraga, karena lektaknya di pusat kota, berada di areal toko olahraga dan cukup dekat dengan beberapa pusat olahraga. Seperti yang disampaikan dalam kutipan wawancara berikut: "pada awal beridiri, kami sudah survey dulu, jadi beberapa tempat yang kita survey, dimana sebaiknya kami membuka perusahaan ini pada tahun 2005. Jadi akhirnya jalan hasannudin ini jadi pilihan kami, karena satu dipinggir jalan utama, mudah dijangkau, kemudian tempat parkir memadai, kemudian ada beberapa lapangan misalnya bulutangkis yang dekat-dekat dengan kita, jadi bisa sangat strategis untuk dijangkau oleh konsumen." (WW, Komunikasi Terbuka, 2021)

"Place, tempat kami sangat strategis, dipusat kota, berada di areal toko olahraga juga dan cukup dekat dengan tempat-tempat olahraga” (MW, Komunikasi Personal, 2021)

Sedangkan pada bisnis online, Govinda sport juga memiliki tempat mendistribusikan produknya. Ketiga informan menjawab, manajemen Govinda Sport telah menerapkan bisnis secara online, yang dimana pemasaran bisnisnya dilakukan melalui beberapa platform online, yaitu: Shopee, Tokopedia, Instagram, Whatsapp dan Line. Sekilas memang tampak berbeda, namun perubahan zaman dan kemajuan teknologi telah membuat perubahan besar pada tempat pendistribusian suatu produk.

Suatu produk atau perusahaan dapat dikenal oleh masyarakat, dengan melakukan promosi. Promosi dilakukan untuk mengenalkan dan menanamkan brand perusahaan di benak calon konsumen (Brand Awareness). Ketiga informan menjawab (WW, MW, dan WS) bahwa perusahaan Govinda Sport melakukan promosi dengan berbagai macam cara, seperti beriklan di televisi, membagiakn kartu nama, memberikan sponsor ke event-event olahraga hingga promosi secara online melalui Instagram. Seperti yang dikutip dalam wawancara dengan informan WW berikut ini: "Promosi, kami juga melalukan dari awal , jadi dari awal kami 
seperti misalnya dengan iklan untuk pertama kali, kemudian memberikan baju yang isi tulisan Govinda Sport dibelakangnya, jadi sehingga orang semakin sering membaca di lapangan, jadi semakin ingat dengan toko kita, jadi sampe ribuan lah baju yang kami berikan dari awal, kemudian juga promosi di telivisi, kemudian ke lapangan-lapangan memberikan kartu nama, kemudian juga memasang spanduk di lapangan dan memberikan sponsor club dan kejuaraan-kejuaraan yang berlangsung di Bali.” (WW, Komunikasi Personal, 2021).

"saat ini mungkin kami fokus promosi pada Instagram terlebih dulu, karena menurut kami, Instagram bisa kami manfaatkan untuk sharing video maupun foto, dan secara cepat, jadi dengan momen ditoko kita abadaikan, kemudian ada promopromo menarik kita upload" (WW, Komunikasi Personal, 2021)

Persaingan yang semakin ketat dan dengan adanya perubahan perilaku konsumen yang sudah semakin teredukasi dengan informasi produk, perlu dilengkapi dengan beberapa strategi lagi. Strategi penting agar perusahaan bisa tetap survive adalah dengan memberikan pelayan terbaik kepada konsumen, sehingga konsumen bisa merasa puas berbelanja ditoko. Informan WS menjawab salah satu cara agar dia bisa memberikan pelayan terbaik adalah dengan mempelajari spesifikasi produk-produk yang dijual di perusahaan, agar bisa menjelaskan dan memberikan informasi dengan baik jika konsumen ada pertanyaan. Senada dengan jawaban informan WS, informan ww juga menjawab, manajemen selalu memberikan pelayanan terbaik kepada konsumen, sehingga bisa tetap eksis di bisnis alat-alat olahraga. Seperti yang dikutip dalam wawancara berikut ini: "Dari dulu memang sih kami terus berusaha menjadi toko olahraga nomor 1 di Bali, jadi kami berusaha dengan memberikan pelayanan yang terbaik, jadi baru datang konsumen itu juga dengan menyapa dan melayani, apa yang diperlukan konsumen." (WW, Komunikasi Personal, 2021).

Selain pelayanan terbaik, strategi lainnya yang tidak kalah penting adalah dengan memanfaatkan teknologi terbaru. Bertujuan untuk hasil yang lebih baik dan pengerjaan yang lebih efisien. Informan WS menjawab, perusahaan sudah menggunakan mesin untuk pemasangan senar dengan teknologi terbaru. Seperti yang dikutip dalam wawancara berikut ini: "ada di toko juga menggunakan mesinmesin dan teknologi terbaru, jadinya kerja juga lebih efisien dan hasilnya pengerjaannya juga lebih akurat." (WS, Komunikasi Personal, 2021)

Strategi toko online dan konvensional di perusahaan Govinda Sport ternyata tidak terlalu jauh berbeda. Baik online maupun konvensional sama-sama memasang strategi harga yang kompetitif. informan WS mengatakan strategi di online, perusahaan memasang harga yang murah untuk produk-produk yang dijual secara online. Senada dengan pernyataan WS, informan MW mengatakan manajemen memasang hargayang murah untuk strategi toko online. Seperti yang dikutip dalam wawancara berikut: "observasi yang saya lihat di dunia bisnis online, perang harga sangat gila-gilaan, disini kami akan terjun dan juga ikut menurunkan harga di toko online kami, sehingga untuk konsumen bisa melihat dululah toko kami. Memang untung akan sangat jauh dibandingkan dengan berjualan konvensional, tapi kami 
mencoba akan mencari keuntungan dari kuantitas barang yang kami jual." (MW, Komunikasi Personal, 2021)

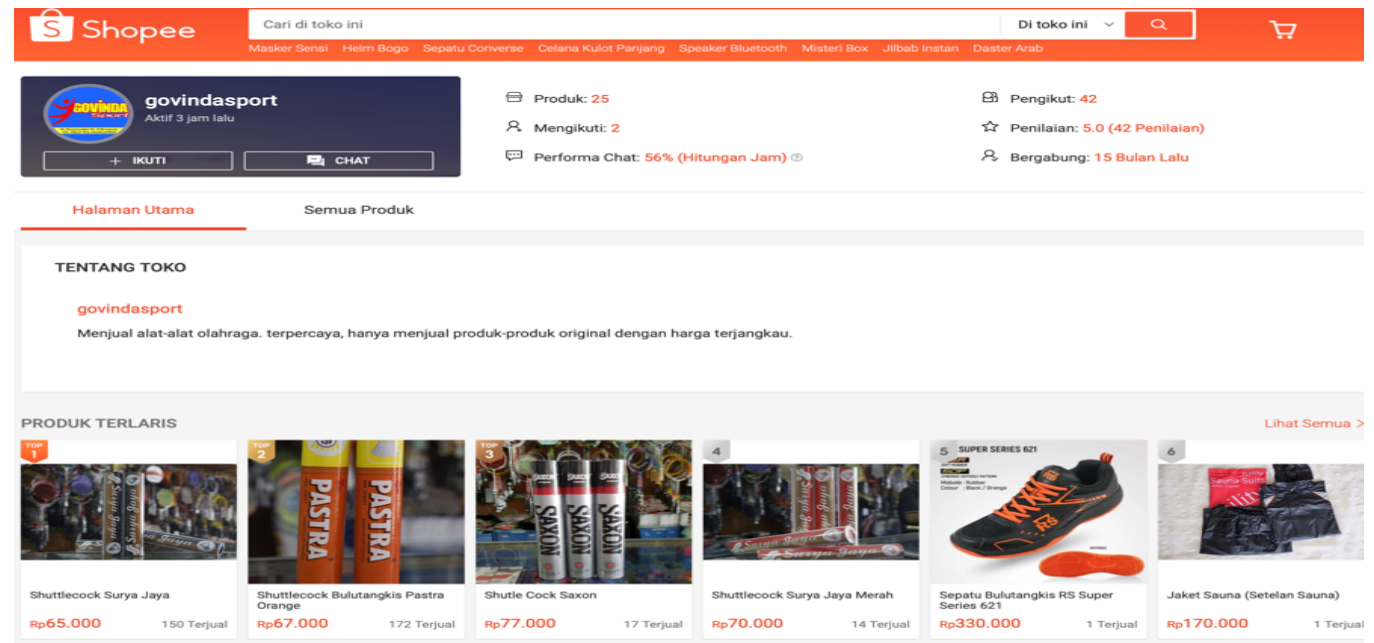

\section{Gambar 2. Shopee Govinda Sport}

Dapat dilihat pada gambar 2 Govinda Sport sudah memiliki toko online di marketplace Shopee. Govinda Sport memiliki tidak terlalu banyak produk yang dijual di Shopee, terdapat hanya 25 produk dan memiliki 42 pengikut. Walaupun demikian, Toko Govinda Sport memiliki nilai review 5.0 dari konsumen, yang artinya konsumen sangat puas dengan pelayanan toko Govinda Sport.

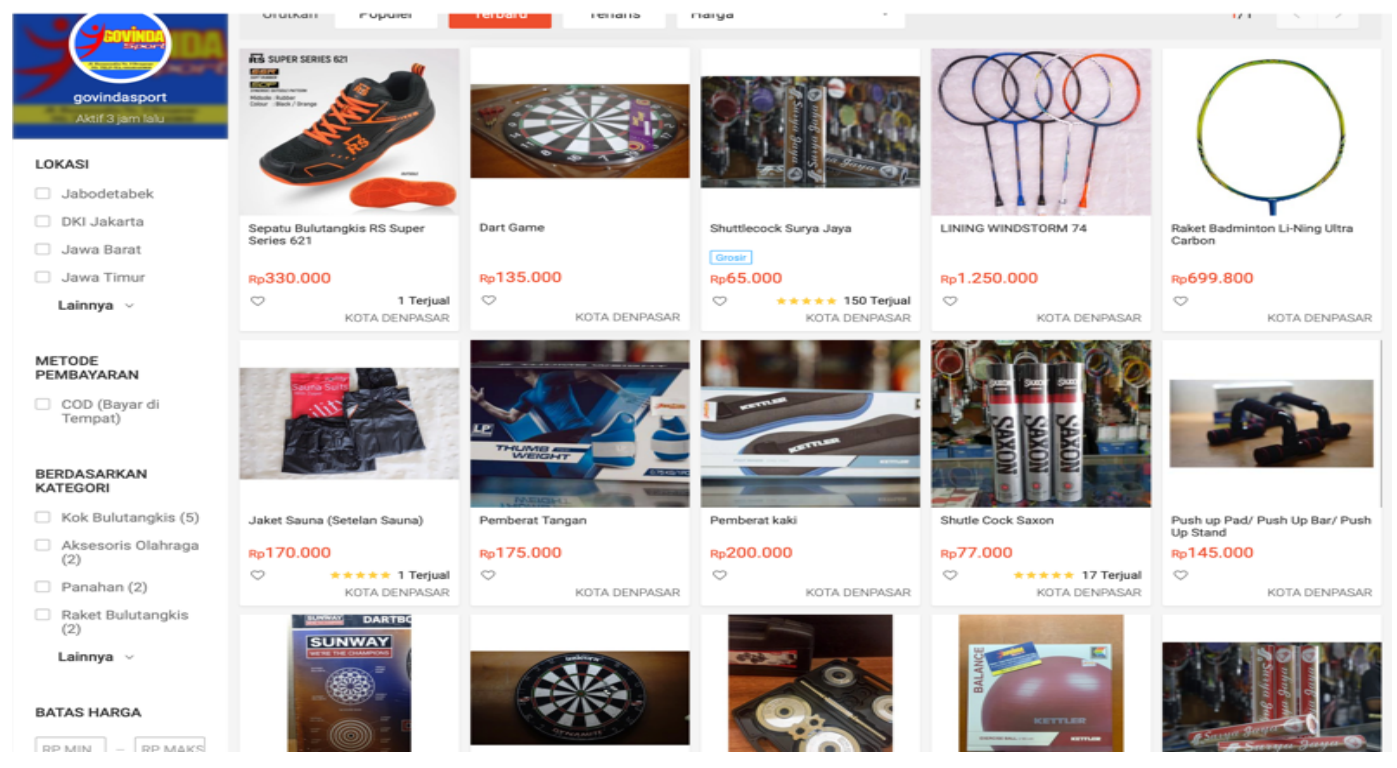

\section{Gambar 3. Tingkat Penjualan Shopee Govinda Sport}

Tingkat penjualan pada marketplace Shopee toko Govinda Sport terlihat masih belum maksimal. Penjualan berulang hanya terjadi pada 3 produk saja, yaitu 
shuttlecock bulutangkis. Selain itu masih banyak produk yang belum pernah terjual. data ini senada dengan data yang disampaikan oleh informann dalam penelitian ini.

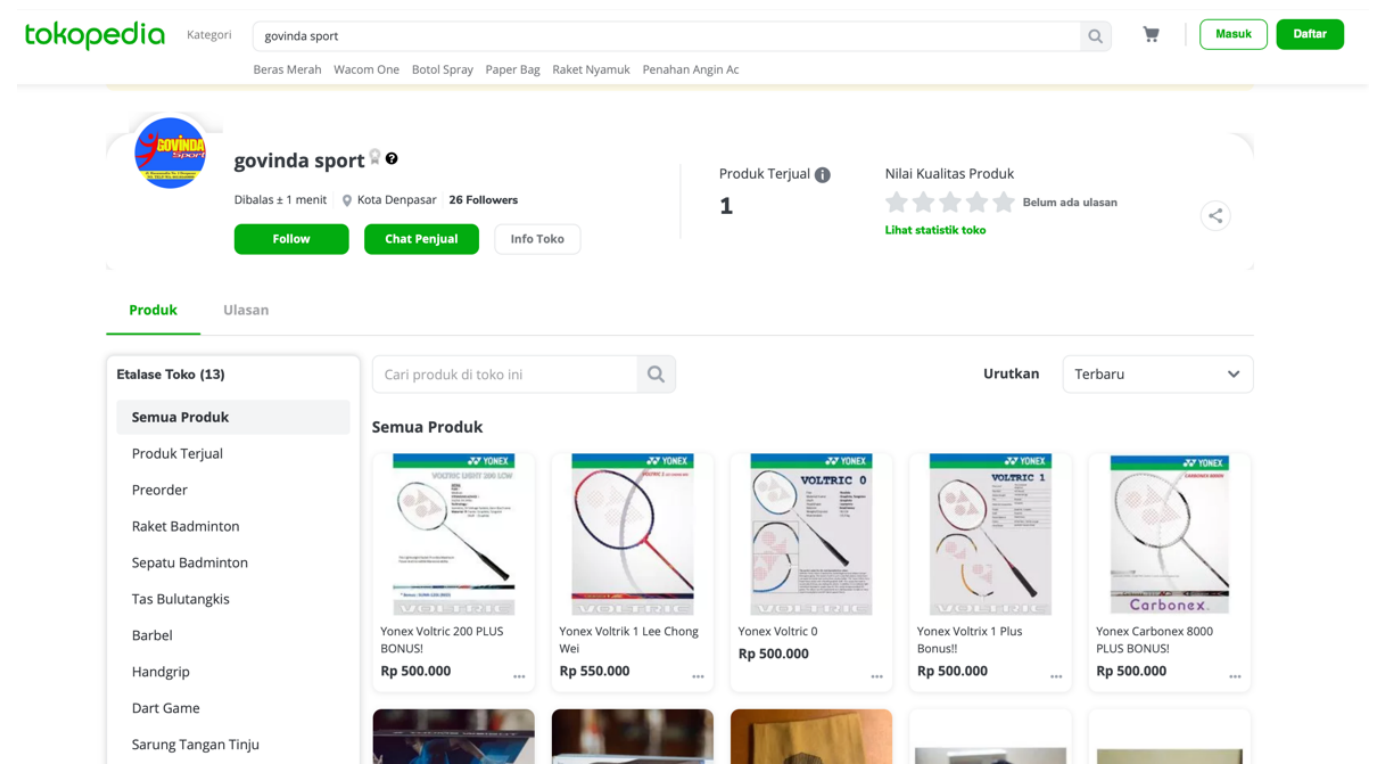

Gambar 4. Tingkat Penjualan di Tokopedia Govinda Sport

Pada marketplace Tokopedia, Govinda Sport juga sudah memiliki toko online. Govinda Sport memiliki dua puluha enam (26) followers dan hanya baru satu produk yang terjual. produk yang dipamerkan dalam etalase toko ada ada tiga belas (13) produk. Dapat dilihat memang tingkat penjualan Govinda Sport pada Tokopedia memang belum tinggi dan toko masih belum efektif.

Keberadaan internet telah banyak berpengaruh terhadap dunia bisnis. Internet dengan kemajuan teknologinya telah membuat dunia bisnis berevolusi ke dunia digital. Tak terkecuali para konsumen yang juga ikut berubah ke dunia digital. Perilaku konsumen telah banyak berubah, yang dulu terbiasa harus datang ke suatu toko untuk memperoleh produk, di zaman sekarang sudah bisa memanfaatkan teknologi untuk berbelanja dari rumah.

Peluang bisnis yang besar membuat pelaku bisnis bergerak untuk selalu dapat mengikuti perkembangan teknologi yang ada, seperti trend saat ini menggunakan media sosial yang bukan hanya dipergunakan untuk berinteraksi jarak jauh tetapi sebagai media jual-beli produk atau jasa. Banyak bisnis yang masih tergolong kecil berhasil mendapatkan keuntungan yang besar berkat penggunaan media sosial

Konsumen mulai banyak transaksi melalui online, seperti Marketplace ataupun Instagram. Alasannya adalah berbagai kelebihan yang didapatkan oleh konsumen, seperti efisien waktu dan tenaga, harga yang sudah pasti, dan ketersediaan berbagai macam varian produk. Seperti pada penelitian yang dilakukan oleh (Khairunnisa, 2014) yang membahas mengenai perilaku konsumtif remaja dalam menggunakan Instagram mendapati hasil yakni sebelum mengenal sosial media Instagram, kebanyakan remaja hanya melakukan aktivitas berbelanja jika memiliki waktu senggang saja, tetapi setelah ada Instagram setiap saat mereka 
dapat selalu melihat contoh barang tersebut atau berbelanja melalui handphone-nya sendiri. Seperti yang dikutip dalam wawancara dengan 3 informan di Kota Denpasar (KW, KSP dan RRG) berikut ini: "Kalau misalkan online saya gaperlu ribet ke toko fisiknya, dan lebih ringkas aja saya make online dibandingkan datang ke toko" (KW, Komunikasi Personal, 2021)

Penelitian oleh Darmawan \& Ekawati (2017) menemukan bahwa, hasil foto mempengaruhi minat pembeli. Itu sebabnya mengapa para konsumen dan penjual lebih suka membeli dan berjualan online melalui Instagram. Hal serupa juga ditemukan pada hasil data penelitian, seperti yang dikutip dari wawancara dengan informan KSP berikut ini: "mungkin kan banyak keluar toko di beranda, tapi saya liat dari produknya, kalau dari foto produknya meyakinkan mungkin saya langsung kesana, tapi kalau dari fotonya kurang meyakinkan, saya jadi kurang percaya" (KSP, Komunikasi Personal, 2021)

Selain dari kualitas foto, review dari konsumen lain juga menjadi pertimbangan untuk konsumen lain untuk melakukan keputusan pembelian. Seperti yang ditemukan dari hasil penelitian yang dilakukan oleh (Tuten \& Perotti, 2019) yang memaparkan hasil bahwa konsumen dapat mempengaruhi konsumen lain melalui review mereka tentang produk bersangkutan di social media, dimana hal ini memberikan dampak langsung terhadap keinginan membeli konsumen akan suatu produk. Hal serupa juga ditemukan pada hasil data yang diperoleh peneliti. Seperti yang dikutip pada wawacara dengan informan berikut ini: "menyediakan barang yang saya butuhkan, kalau dia punya jangkauan kerjanya sesuai dengan yang saya cari, harga dan ketersediaan barang, ada atau tidaknya pricelist di tokonya tersebut, kadang di online shop cuma display barang saja jadi tidak ada info buat konsumen, jadi kayak bingung sendiri, jadi atau tidak belanja" (KW, Komunikasi Personal, 2021)

Seperti yang dapat dilihat baik dari hasil data yang diperoleh maupun data dari penelitian sebelumnya, terdapat berbagai macam keuntungan yang diperoleh konsumen dengan melakukan transaksi online. berbagai kelebihan ini telah membuat trend baru konsumen olahraga, yang menjadi terbiasa melakukan transaksi online. Perubahan perilaku konsumen yang memilih berbelanja melaui online sudah banyak terjadi seperti data yang sudah diperoleh. Ini disebabkan oleh keuntungan yang didapatkan oleh konsumen dengan berbelanja melalui online, dimana konsumen akan lebih hemat waktu dan tenaga, kemudian harga yang sudah jelas tertera di toko online dan banyaknya pilihan varian produk.

Perubahan perilaku konsumen ke online shopping perlu disikapi dengan strategi yang tepat oleh manajemen perusahaan, sehingga perusahaan bisa tetap bersaing dan berkembang. Salah satu strategi yang biasat digunakan adalah bauran pemasaran. Pupuani \& Sulistyawati (2013) menyatakan "Perusahaan dalam mencapai tujuan pemasarannya di dalam pasar sasaran menggunakan seperangkat alat pemasaran bernama bauran pemasaran." Pratiwi \& Mandala (2015) memaparkan hasil bahwa "bauran pemasaran merupakan variabel paling dominan yang berpengaruh terhadap keputusan pembelian Kebaya bordir pada Jegeg Ayu." Manajemen Govinda Sport sudah menerapkan strategi Bauran Pemasaran 4P, seperti yang dikutip dari wawancara dengan ketiga informan (WW, MW, dan WS) 
Product. Marketing mix yang diterapkan pertama adalah strategi produk, dimana ketiga informan (WW, MW, dan WS) menjawab manajemen Govinda Sport hanya menjual produk original dan berkualitas tinggi.

Price. Ketiga informan (WW, MW, dan WS) menjawab, bahwa manejemen Govinda Sport selalu memberikan harga yang kompetitif dan terbaik, untuk menyikapi persaingan di bisnis konvensional maupun bisnis online.

Place. Informan WW dan MW menjawab, lokasi Govinda Sport saat ini merupakan lokasi yang strategis untuk menjalankan bisnis alat-alat olahraga, karena lektaknya di pusat kota, berada di areal toko olahraga dan cukup dekat dengan beberapa pusat olahraga.

Promotion. Informan WW menjawab bahwa perusahaan Govinda Sport melakukan promosi dengan berbagai macam cara, seperti beriklan di televisi, membagiakn kartu nama, memberikan sponsor ke event-event olahraga hingga promosi secara online melalui Instagram.

Strategi Marketing Mix sudah diterapkan oleh manajemen Govinda Sport baik untuk toko kenvensional maupun toko onlinenya. Setelah stratergi tersebut diterapkan, ada beberapa strategi tambahan untuk memaksimalkan toko online. strategi ini dilakukan adalah untuk menyikapi perubahan perilaku konsumen ke online shopping, diantaranya adalah menggiring konsumen berbelanja di marketplace Toko Govinda sport melalui Promosi di Instagram, memberikan harga yang lebih murah di toko online dan menambah tenaga SDM di bidang digital marketing.

\section{SIMPULAN}

Hasil penelitian kepada konsumen olahraga, dimana informan sudah pernah melakukan transaksi melalui media online. Informan merasakan banyak keuntungan saat melakukan belanja online diantaranya, lebih efisien waktu, terdapat banyak varian produk dan bisa berkomunikasi pada saat itu juga. Akan tetapi dengan berbagai keuntungan, juga terdapat kekurangan berbelanja online yaitu tidak dapat melihat kondisi fisik barang secara langsung dan risiko barang rusak saat pengiriman. Hal tersebut membuat informan masih akan tetap melakukan transaksi secara konvensional untuk barang-barang tertentu. Informan akan lebih banyak melakukan transaksi peralatan olahraga melalui online dibandingkan konvensional.

Berdasarkan hasil penelitian pada konsumen olahraga di Kota Denpasar yang ditemukan hasil, bahwa sebagian besar pembelian perlatan olaharga dilakukan secara online, Toko Govinda Sport juga akan menyikapi dengan strategi yang sudah disiapkan. Pada toko olahraga Govinda Sport, didapatkan hasil bahwa, manajemen Govinda Sport telah menerapkan strategi Bauran Pemasaran 4P pada toko konvensional dan toko Online. Disamping itu perusahaan Govinda Sport sudah terjun ke dunia bisnis online, akan tetapi bisnis onlinenya belum terlalu efektif. Keuntungan yang didapat pada bisnis online masih jauh lebih sedikit dengan keuntungan pada toko konvensionalnya, ini disebabkan oleh tingkat penjualan yang masih rendah dan belum terdapat SDM yang memiliki keahlian dibidang digital marketing. Strategi yang dilakukan oleh manajemen untuk lebih bisa bersaing di dunia bisnis online adalah dengan cara menambah SDM dibidang digital marketing, 
melakukan promosi di Instagram dan kemudian mendorong kosumen untuk bertransaksi melalui toko online Govinda Sport yang di marketplace. Strategi bauran pemasaran belum cukup untuk bisa bersaing di bisnis online, konsumen membutuhkan pengelaman, konten seperti foto produk yang berkualitas serta edukasi suatu tentang produk.

Berdasarkan temuan penelitian ini, diharapkan untuk dapat mengembangkan strategi pemasaran yang lainnya, karena patut disadari bahwa terdapat beberapa keterbatasan dari penelitian ini yang diantaranya ruang lingkup penelitian terbatas pada wilayah Kota Denpasar, sehingga hasil penelitian ini tidak dapat digeneralisasi untuk konsumen di wilayah yang lebih luas serta mengingat penelitian ini dilakukan dalam jangka waktu tertentu (cross section) sedangkan lingkungan mengalami perubahan, maka penelitian ini penting dilakukan di masa yang akan datang.

\section{REFERENSI}

Adinata, K. J., \& Yasa, N. N. K. (2018). Pengaruh Kepercayaan, Persepsi Harga, Dan Sikap Terhadap Niat Beli Kembali Di Situs Lazada. E-Jurnal Manajemen Universitas Udayana, 7(8), https://doi.org/10.24843/ejmunud.2018.v07.i08.p05

Adnyana, R., \& Darma, G. S. (2015). Strategi Marketing Mix, Yield Management, Customer Satifaction and Occupany Rate. Jurnal Manajemen Dan Bisnis, 12(1), 99-121. http://journal.undiknas.ac.id/

Arthur, K. M., Asmara, A., \& Simanjuntak, M. (2019). the Effect of Marketing Mix on "Kpr Xtra Bebas" Decision Making in Bank X Regional I. Journal of Consumer Sciences, 4(1), 1. https://doi.org/10.29244/jcs.4.1.1-12

Darmawan, P. A. D. T., \& Ekawati, N. W. (2017). Pengaruh Kepuasan Konsumen Memediasi Harga Terhadap Loyalitas Konsumen Dalam Berbelanja Pada Florist Online Di Denpasar. E-Jurnal Manajemen Universitas Udayana, 6(4), 255298 .

Devi, P. S. C., \& Sulistyawati, E. (2018). Peran Customer Satisfaction Memediasi Pengaruh Online Trust Terhadap Repurchase Intention ( Studi pada Konsumen Florist Online di Kota Denpasar ). E-Jurnal Manajemen Universitas Udayana, 7(6), 2856-2886.

Dewi, M. V. K., \& Darma, G. S. (2019). The Role of Marketing \& COmpatitive Intelligence In Industrial Revolution 4.0. Jurnal Manajemen Dan Bisnis, 16(1), $\quad 1-12 . \quad$ http://journal.undiknas.ac.id/index.php/magistermanajemen/http://journal.undiknas.ac.id/index.php/magister-manajemen/

Edward, P., \& Wibowo, S. \&. (2019). The effect on marketing mix on consumer purchase decision on bright gas product in Medan (study in PT Pertamina (Persero) marketing operation region 1). International Journal of Research \& 
Review, 6(10), 8 .

Endyana, M. D. A., \& Ardani, I. G. A. K. S. (2019). Peran Brand Awareness Memediasi Pengaruh Advertising Terhadap Keputusan Pembelian. E-Jurnal Manajemen Universitas $\quad$ Udayana, $8(11), \quad 6558$. https://doi.org/10.24843/ejmunud.2019.v08.i11.p09

Foster, B., \& Johansyah, M. D. (2019). The effect of product quality and price on buying interest with risk as intervening variables (study on Lazada.com site users). International Journal of Innovation, Creativity and Change, 9(12), 6678.

Hanaysha, J. R. (2018). An examination of the factors affecting consumer's purchase decision in the Malaysian retail market. PSU Research Review, 2(1), 7-23. https://doi.org/https://doi.org/10.1108/PRR-08-2017-0034

Handika, M. R., Maradona, A. F., \& Darma, G. S. (2018). Strategi Pemasaran Bisnis Kuliner Menggunakan Influencer Melalui Media Sosial Instagram. Manajemen Dan Bisnis Undiknas, 15(2), 192-203.

Khairunnisa. (2014). Dampak Aplikasi Instagram Terhadap Perilaku Konsumtif Remaja Dalam Berbelanja Online Di Kalangan Siswa-Siswi SMA Negeri 2 Tenggarong. EJournal Ilmu Komunikasi, 2(4), 220-230.

Li, F., Larimo, J., \& Leonidou, L. C. (2021). Social media marketing strategy: definition, conceptualization, taxonomy, validation, and future agenda. Journal of the Academy of Marketing Science, 49(1), 51-70. https://doi.org/10.1007/s11747-020-00733-3

Maharani, I. G. A. P. D., \& Darma, G. S. (2018). Consumer Purchasing Behavior Analysis on Impulse Buying. Jurnal Manajemen Dan Bisnis, 15(3), 16-37.

Maharani, N. L. P. A., \& Ekawati, N. W. (2019). Peran Kepuasan Konsumen Memediasi Pengaruh Harga Terhadap Loyalitas Konsumen dalam Berbelanja Clothing Online Melalui Instagram. E-Jurnal Manajemen Universitas Udayana, 8(9), 5672-5701.

Mahardhika, W. B., \& Sunariani, N. N. (2019). Strategi Pemasaran Produk Makanan Catering Melalui Media Sosial Instagram. Jurnal Manajemen Dan Bisnis, 16(1), 13-27. http://journal.undiknas.ac.id/index.php/magistermanajemen/

Maia, C. R., Lunardi, G. L., Dolci, D., \& D’Avila, L. C. (2019). Competitive price and trust as determinants of purchase intention in social commerce. $B A R$ Brazilian Administration Review, 16(4), 1-24. https://doi.org/10.1590/18077692 bar2019190074 
Martha, R. E., Evanita, S., \& Patricia, D. (2019). The Influence of Promotion Mix towards Purchasing Decision of Indihome product in Telkom Region of Padang City. Advances in Economics, Business and Management Research, 64(2014), 686-690. https://doi.org/10.2991/piceeba2-18.2019.53

Martinayanti, N. M. P., \& Setiawan, P. Y. (2016). Peran Kepercayaan Dalam Memediasi Persepsi Risiko Pada Niat Beli Produk Fashion Via Instagram Di Kota Denpasar. E-Jurnal Manajemen Universitas Udayana, 5(4), 2026-2053.

Mulya Firdausy, C., \& Idawati, R. (2017). Effects of Service Quality, Price and Promotion on Customers' Purchase Decision of Traveloka Online Airline Tickets in Jakarta, Indonesia. International Journal of Management Science and Business Administration, 3(2), 42-49. https://doi.org/10.18775/ijmsba.1849-5664-5419.2014.32.1004

Nusarika, L. A. K., \& Purnami, N. M. P. (2015). Pengaruh Persepsi Harga, Kepercayaan, Dan Orientasi Belanja Terhadap Niat Beli Secara Online (Studi Pada Produk Fashion Online Di Kota Denpasar). E-Jurnal Manajemen Universitas Udayana, 4(8), 254393.

Pee, L. G. (2016). Negative online consumer reviews: Can the impact be mitigated? International Journal of Market Research, 58(4), 545-568. https://doi.org/10.2501/IJMR-2016-035

Pratiwi, K. I., \& Mandala, K. (2015). Pengaruh Faktor Budaya, Sosial, Pribadi, Psikologis, Dan Bauran Pemasaran Terhadap Keputusan Pembelian Kebaya Bordir Pada Jegeg Ayu Boutique Di Kuta. E-Jurnal Manajemen Universitas Udayana, 4(11), 255236.

Pupuani, N., \& Sulistyawati, E. (2013). Pengaruh Bauran Pemasaran Terhadap Kepuasan Konsumen Dan Perilaku Pembelian Ulang (Studi Kasus Pada Produk Pasta Gigi Merek Pepsodent Di Kota Denpasar). E-Jurnal Manajemen Universitas Udayana, 2(6), 255275.

Putra, I. B. F. E., \& Prianthara, I. B. T. (2019). Strategi Bisnis E-Commerce Dalam Optimalisasi Tingkat Hunian Kamar Hotel Dan Villa. Jurnal Manajemen Dan Bisnis, 16(1), 28-43.

Putra, I. G. N. A. P., \& Darma, G. S. (2019). Is Bitcoin Accepted in Indonesia? International Journal of Innovative Science and Research Technology, 4(2), 424-430.

content/uploads/2019/03/IJISRT19FB185v2.pdf

Putri, C. I. D., \& Sudiksa, I. B. (2018). Peran Kepercayaan Dalam Memediasi Pengaruh Persepsi Risiko Terhadap Niat Beli Online Pada Situs Lazada. EJurnal Manajemen Universitas Udayana, 7(7), 3532. 
https://doi.org/10.24843/EJMUNUD.2018.v07.i07.p04

Sianturi, C. I., Rini, E. S., \& Sembiring, B. K. F. (2019). The Influence of Service Quality and Promotion on Consumers' Repurchase Decision with Shopping Life Style as a Variable Moderating at Franchise Minimarket in Medan. International Journal of Research and Review, 6(May), 32-39.

Sidharta, I., \& Boy Suzanto. (2015). Pengaruh Kepuasan Transaksi Online Shopping Dan Kepercayaan Konsumen Terhadap Sikap Serta Perilaku Konsumen Pada E-Commerce. Jurnal Computech \& Bisnis, 9(1), 23-36. http://jurnal.stmik-mi.ac.id/index.php/jcb/article/download/124/148

Solihin, F., Yulisetiarini, D., Wihelmina, I. D., \& Wardana, F. R. (2019). The effect of green marketing strategy on purchasing decisions: A review of previous research. International Journal of Scientific and Technology Research, 8(12), $3662-3665$.

Sugiyono. (2018). Metode Penelitian Kuantitatif, Kualitatif, dan R\&D. Alfabeta.

Suhaily, L., \& Soelasih, Y. (2017). What Effects Repurchase Intention of Online Shopping. International Business Research, 10(12), 113. https://doi.org/10.5539/ibr.v10n12p113

Sujana, K. C., \& Suprapti, N. W. S. (2016). Peran Kepercayaan Dalam Memediasi Pengaruh Kualitas Situs Terhadap Niat Konsumen Untuk Berbelanja Di Situs Zalora. E-Jurnal Manajemen, 5(1), 252950.

Sutedjo, B., \& Oetomo, D. (2015). Pengaruh Web dalam Komunikasi Pemasaran untuk Meningkatkan Perhatian dan Ketertarikan Konsumen Online. Jurnal Eksplorasi Karya Sistem Informasi Dan Sains, 8(2), 94-106. http://id.portalgaruda.org/index.php?ref=browse\&mod=viewarticle\&article= 358193

Tanzil, F. E., \& Kusuma, G. A. A. (2015). Pengaruh Bauran Pemasaran Pada Keputusan Pembelian Ulang Kebaya Di Rumah Kebaya Bali Molek. Jurnal Manajemen Dan Bisnis, 4(5), 1336-1344.

Tejantara, A., \& Sukawati, G. T. (2018). Pelanggan Untuk Meningkatkan Niat Pembelian Ulang (Studi Pada Oli Sepada Motor Merek Eni di Kota Denpasar). Jurnal Manajemen Dan Bisnis, 7(10), 5686-5718.

Tuten, T., \& Perotti, V. (2019). Lies, brands and social media. Qualitative Market Research, 22(1), 5-13. https://doi.org/10.1108/QMR-02-2017-0063

Uslu, A., \& Huseynli, B. (2018). Impact Of Price Sensitivity On Repurchase Intention In Terms Of Personality Features. Uluslararası İktisadi ve İari 
Incelemeler Dergisi, 1(August), 1. https://doi.org/10.18092/ulikidince.434866

Vinerean, S. (2017). Content Marketing Strategy. Definition, Objectives and Tactics. Expert Journal of Marketing, 5(2), 92-98.

Widana, I. W., \& Darma, G. S. (2018). Branding Denpasar Smart City Guna Meningkatkan Kunjungan Wisatawan. Jurnal Manajemen Dan Bisnis, 15(1), 176-199.

Widani, N. M., Abiyasa, A. P., Darma, G. S., \& Maradona, A. F. (2019). Menguji Ketajaman Implementasi E-Commerce Dalam Penjualan Kamar Hotel di Bali. Jurnal Manajemen Dan Bisnis, 16(2), 79-98.

Yasri, Y., Susanto, P., Hoque, M. E., \& Gusti, M. A. (2020). Price perception and price appearance on repurchase intention of Gen Y: do brand experience and brand preference mediate? Heliyon, 6(11), e05532. https://doi.org/10.1016/j.heliyon.2020.e05532 